\title{
Regional Review of Payments for Watershed Services: Sub-Saharan Africa
}

Author:

Paul J. Ferraro

\section{Prepared by:}

Sustainable Agriculture and Natural Resource Management Collaborative Research Support Program (SANREM CRSP)

Office of International Research, Education, and Development (OIRED), Virginia Tech

E-mail: oired@vt.edu

On the Web: www.oired.vt.edu

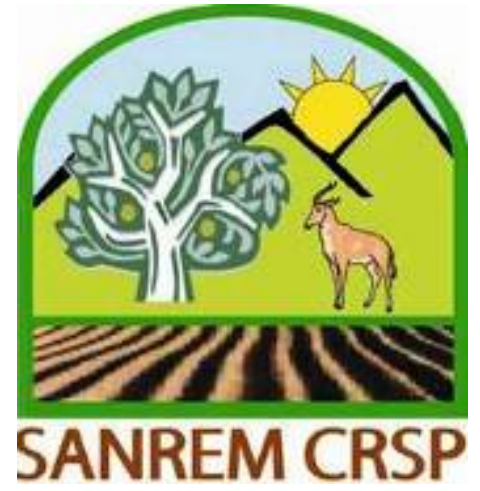


Submitted by Paul J. Ferraro, Department of Economics, Andrew Young School of Policy Studies, Georgia State University, P.O. Box 3992, Atlanta, GA 30302-3992

Submitted to SANREM CRSP, Virginia Polytechnic Institute and State University, Agreement No. EPA-A-00-06-00004-00, Global Assessment of Best Practices for Ecosystem Services Programs 


\section{Regional Review of Payments for Watershed Services: Sub-Saharan Africa}

\section{Introduction}

Although there has been global experimentation with Payments for Watershed Service (PWS) schemes for almost a decade, only a couple of schemes exist in Africa. ${ }^{1}$ The two African PWS programs that are currently making payments are both located in South Africa. As described below, these two programs have characteristics that are unusual when compared to PWS schemes in Latin America and Asia: they are essentially public works programs oriented towards securing hydrologic services. Given that the most common definitions of Payments for Environmental Services (PES) in the literature do not include such public works programs (e.g., Wunder, 2007; Ferraro, 2001), one could reasonably argue that there are no PWS schemes currently operating in Africa.

To define a PES, this review adapts Wunder's (2007) definition of a PES with two extensions. ${ }^{2}$ A PES is a voluntary transaction in which an environmental service buyer, who does not control the environmental factors of production, pays an environmental service provider, who controls the environmental factors of production, for a well-defined environmental service using a cash or in-kind payment that varies conditional on the quantity and quality of the environmental service provided. Of course, there may be more than one buyer or seller involved in the transaction. Furthermore, the service itself may be costly to observe and thus the payment may be tied to observable performance that is correlated with the quality and quantity of the desired service (e.g., paying landowners to create riparian buffers that reduce runoff into nearby surface waters). ${ }^{3}$

In addition to the two programs in South Africa, there are at least eight other initiatives in formal planning phases in South Africa, Tanzania, and Kenya. Presentations at recent workshops (e.g., East and Southern Africa Katoomba Group, 2006) suggest that other initiatives are being considered by field practitioners and government agencies, but have not yet entered a formal planning phase.

Given the paucity of on-the-ground PWS initiatives, one cannot write about an "African PWS model” or "regional PWS trends in Africa." Thus this review has two objectives: (1) briefly characterize the South African initiatives and the proposed initiatives in other nations; and (2) describe the factors that likely cause Africa to have fewer PWS schemes than Latin America and other regions, where there are tens of such initiatives. The latter exercise is intended to help natural resource management and development practitioners think about the field characteristics under which PWS programs can succeed.

\section{Payments for Environmental Services in Africa}

For all types of environmental services, Africa lags Latin America and Asia in the development of Payments for Environmental Services (PES) schemes. For example, in the global carbon offset market for 2003 and 2004, Latin America and Asia accounted for more than three-quarters of the emissions

\footnotetext{
${ }^{1}$ Because North Africa is often lumped cultural and biophysically with the Middle East, this review focuses on SubSaharan Africa. North Africa has no documented PWS schemes to date.

${ }^{2}$ The extensions are: (1) the supplier controls the factors of production; and (2) the payment varies with the level of environmental performance. The first extension implies, for example, that the wages or fees a farmer pays to laborers to construct a riparian vegetative strip on the farmer's land are not considered payments for environmental services. The second extension implies that offering someone a school or land title in exchange for a promise to provide environmental services is not a PES unless the amount of school or land title can be varied with performance (e.g., part of the school is destroyed or some of the rights inherent in the title are rescinded if the quality or quantity of services is lower than promised).

${ }^{3}$ Much like a private firm's manager, whose exact contributions to short-run and long-run profits are not easily observed, may receive compensation based on observable actions or indicators that owners believe are correlated with these profits.
} 
reduction projects. Africa accounted for only three percent (Lecocq and Capoor, 2005). ${ }^{4}$ Relative to other areas of the world, Africa also had fewer projects under preparation (Lecocq and Capoor, 2005).

The Katoomba Group commissioned PES inventories for Uganda (Ruhweza and Masiga, 2006), Kenya (Mutunga and Mwangi, 2006), Tanzania (Scurrah-Ehrhart 2006) and South Africa (King, Damon and Forsyth, 2005). ${ }^{5}$ These inventories list eighteen biodiversity projects (of which two are making payments, in cash or in kind), seventeen carbon projects (of which five are making payments), and ten water projects (of which two are making payments). Jindal (2006) lists another thirteen nations with carbon sequestration projects, but none of them have more than one project (Kenya, Tanzania and Uganda together have seven projects). A couple other nations have biodiversity payment initiatives (Madagascar, Guinea). ${ }^{6}$ However, no other payments for water services initiatives were identified. Bond (2006a) reports that PWS schemes were proposed in Zimbabwe and Malawi, but later abandoned. Examples of non-watershed services PES and PES-like activities in Africa are shown in Table 1.

The inventories' definition of what a "payment for biodiversity" project comprises in Africa (as well as the definition used in many other documents and presentations on PES in Africa) includes community-based natural resource management initiatives, ecotourism market participation (e.g., as guides or other tourist service providers), agricultural technology transfer projects, and projects that reward communities with limited access to protected areas. ${ }^{7}$ A minority of the listed projects are conditional (performance-based). The Kenyan inventory lists ten PES projects (one water, one carbon and eight biodiversity) but has a disclaimer at the top which states, "The projects show elements of PES but may not necessarily exhibit explicit characteristics of the buyer-seller model.” The Ugandan inventory includes, as a payment initiative for water services, the Uganda Breweries Limited wetlands program, in which the company has installed technology to reduce its pollution of the wetlands and has funded the government's public education efforts about wetlands.

A recent workshop aimed at "Catalyzing Payments for Ecosystem Services in Africa" further illustrates the paucity of initiatives (East and Southern Africa Katoomba Group, 2006). Of the eight African case studies presented from four nations, only one is about an on-going PES project; five are about the "potential for PES" in three nations, one is about implications of another initiative for thinking about PES, and one calls itself a PES, but the actual initiative is no different from a typical development project. $^{8}$

Most African PES initiatives are funded through overseas development assistance, international conservation organizations, and increasingly, governmental agencies. There is currently little private sector involvement. A common refrain at PES meetings is that somehow conservation and development practitioners must "engage the private sector," which currently is unaware of the substantial purported gains from trade in environmental service contract schemes. Whether private sector involvement in PWS in Africa is likely or not is explored in section 4. In the next section, existing and planned PWS initiatives are examined more closely.

\section{Payments for Water Services (PWS) in Africa}

Below, two on-going payment programs in South Africa, as well as four other initiatives in South Africa and two in East Africa that are in the planning phases, are briefly described. The latter six proposed projects may or may not describe the future of PWS in Africa. Bond (2006a) found that of sixteen PWS proposals made globally in 2002, nine were abandoned by 2006, three were still proposals,

4 In sub-Saharan Africa, only Uganda and South Africa had any large-scale transactions, and only a half dozen other

Sub-Saharan nations were preparing projects as of April 2005.

${ }^{5}$ Inventories are pending for Malawi and Madagascar.

${ }^{6}$ See http://epp.gsu.edu/pferraro/special/ci/index.html.

${ }^{7}$ Offering limited access is more like a cost-sharing program than a payment for the provision of environmental services.

${ }^{8}$ Villagers were offered a mix of suasion, coercion and token compensation to re-vegetate river banks. 
and the other four were in progress ("in progress," however, does not imply payments are being made yet).

\subsection{Working for Water (WfW) Program, South Africa ${ }^{9}$}

Launched in 1995, the Working for Water (WfW) program is a public works initiative that employs low-skilled, unemployed laborers and "historically disadvantaged individuals" (rural women, youth and the disabled). The contracted laborers remove invasive plant species that are established in about $10 \%$ of South Africa's total land area (about 10 million hectares). Over the last two decades, South African scientists have developed a strong scientific foundation that documents the effects of invasive plants on the South African environment and the most effective methods for controlling them. Invasive plants are estimated to use $7 \%$ of all water resources, as well as intensifying floods and fires, and threatening native biodiversity.

Working for Water was created with the intention of contributing toward the newly elected (1994) democratic government's goals of alleviating poverty, creating jobs, empowering the poor economically, and rectifying inequities created from decades of apartheid rule. Although it does little environmental targeting, it engages in strict social targeting. The WfW system encourages small-business entrepreneurs (particularly less experienced ones) to bid on WfW contracts for land management units where invasive species removal has been identified as important to increase water flows. Part of the WfW's mission is to encourage small business development as a form of social empowerment in poor communities.

WfW also has elaborate, affirmative action hiring protocols to ensure that the independent contractors focus on employing low-skilled, unemployed citizens, with a particular emphasis on women, youth, and the disabled (including HIV-infected individuals). Wages are set by WfW, and contractors are instructed that they must hire only the formerly unemployed and achieve hiring targets for women, youth and the disabled. Because of its emphasis on economic empowerment and working with largely unskilled labor in poor communities, WfW has a substantial training program that runs the gamut from workrelated skills (e.g., machine operation) to general life skills (e.g., health education). The number of days of training an employee receives is a function of the number of days they work each month.

Most of WfW's activities are on public lands. For private land where the owner has not paid for WfW services, preference is given to emerging farmers (full funding) and land that is deemed a priority with regard to the "holistic clearing strategy" of WfW (80\% funding for first two clearings, $60 \%$ for third). Private land that is not deemed a priority may be given incentives in the form of expertise, herbicides or a maximum of $50 \%$ funding.

WfW's annual budget is currently a little more than 500 million Rand (over US \$70 million). Most of the budget ( $80 \%$ ) comes from general tax revenues from the central government through its Poverty Relief Fund. The next largest contribution (nearly the rest of the budget) comes from the Department of Water Affairs and Forestry's general budget, about which a little more than half comes from "water resource management fees" charged in thirteen of the nations' nineteen Water Management Areas. In order of decreasing importance, foreign donors, municipalities, and the private sector comprise the remaining small fraction of the WfW budget.

Since its inception, WfW has cleared more than one million hectares of invasive plants. In recent years, the program has been clearing almost 200,000 hectares each year while employing 25,000 to 32,000 people annually. While these figures are impressive, South Africa's invasive species problem is enormous and the WfW has not reversed the spread of invasive plants across South Africa. Supporters contend, however, the spread would have been worse in the absence of the WfW. Although no careful empirical evaluations have tested this hypothesis, one might reasonably assume that much of the plants removed would not have been removed without the program. Thus by using hydrologic models that

\footnotetext{
${ }^{9}$ Sources: Documents, including annual reports, from http://www.dwaf.gov.za/WfWI. Conversations with Christo Marais of the $W f W$. Information on municipal and private sector involvement from Turpie (2004), Turpie and Blignaut (2005), and participant comments at the East and Southern Africa Katoomba Group meeting (2006).
} 
relate area and species cleared to water flow, an estimate of the additional water flow provided by the program can be estimated. One study reports additional water flows as a result of the WfW equal to 250 million $\mathrm{m}^{3}$ annually (Turpie and Blignaut 2005).

The WfW program is essentially a government paying to secure services on governmentcontrolled lands. Thus many PWS proponents would not consider it to be a PWS initiative. Rather than enter this debate, it can be emphasized that the infrastructure established by the WfW can permit activities that are more consistent with the use of the term "PWS" in the literature. The Department of Water Affairs and Forestry has been trying to encourage voluntary payments from private and municipal actors with catchments infested with invasive plants. A few municipalities, state-owned utilities, and private companies have paid into the WfW program in order to have WfW teams clear invasive species from the catchments from which the payers obtain their water supplies. Rather than incur the costs of setting up their own systems for invasive species removal, these local and private actors took advantage of the WfW institutional infrastructure. Such transactions are closer to what PWS proponents describe as "true" PWS programs. Note also that the WfW structure also offers opportunities for foreign donors, like the Global Environment Facility, to invest in removing invasive species that threaten the habitats of globally important biodiversity.

\subsection{Working for Wetlands (WfWet) program, South Africa ${ }^{10}$}

Working for Wetlands (WfWet) was informally started in 2000 when the Working for Water (WfW) program rehabilitated some wetlands. WfWet became a separate program in 2001 and, in 2003, its management was taken over by the South African National Biodiversity Institute (SANBI) on behalf of the departments of Environmental Affairs and Tourism, Water Affairs and Forestry, and Agriculture. Management by SANBI, under the Department of Environmental Affairs and Tourism, underscores the greater environmental emphasis of WfWet compared with WfW. Nevertheless, the model through which WfWet achieves its environmental goals is the same as WfW: a public works program that focuses on employment creation and training for the unemployed and historically disadvantaged individuals.

Wetland rehabilitation requires more than simply clearing invasive plant species. It requires highly skilled planning and engineering labor, as well as more careful environmental targeting. Thus, WfWet has a less onerous hiring protocol for contractors than WfW. The most important aspects of the contractor bid are price and technical merit. Only 10 out of 100 points allocated to a contract in the bidding system are designated for details related to participation by disenfranchised individuals, women and disabled people. For the labor intensive portions of the projects similar criteria to WfW are used to ensure the hiring of the unemployed with the same percentage targets for women, youth and the disabled. Due to the amount of engineering involved with some of the projects, equipment operators can receive higher pay than laborers. Moreover, unlike the WfW program, WfWet prioritizes the wetlands slated for rehabilitation based on biophysical characteristics with less regard paid to the land ownership. WfWet first identifies its priority catchments, and then narrows the choice by site and landowner criteria (current use, perceived value, etc.).

Like WfW, the vast majority of WfWet's budget (67 million Rand in 2006) comes from the Poverty Relief Fund. Some other funds come from international donors/conservation groups. For the 2006 fiscal year, WfWet is implementing forty-two projects covering all provinces, employing almost seventeen hundred people from the target population of poor and historically disadvantaged, and rehabilitating 157,000 square miles of degraded wetlands. Funding for long-term maintenance and protection is a concern, but there are plans for follow-up support and regulation enforcement to maintain the benefits of rehabilitated wetlands over time.

\subsection{Proposed Projects in South Africa ${ }^{11}$}

${ }^{10}$ Sources: http://www.sanbi.org/research/wetlandprog.htm
${ }^{11}$ Sources are cited in text. 
King, Damon and Forsyth (2005) list five other South African PWS initiatives that are in the planning stages: (1) Ga-Selati River, Olifants Catchment project; (2) Maloti-Drakensberg Transfrontier project; and (3) three initiatives in the Sabie River, Sabie-Sand catchment. These five proposed initiatives are structured more like traditional PWS initiatives than the two South African initiatives described above.

In the Ga-Selati River catchment, proponents of the initiative envision downstream users paying upstream land managers to change land use practices to increase flows and reduce sediment. A mine in this catchment already leases 500 hectares from an upstream rural community to protect the riparian zone of their water source (Turpie and Blignaut, 2005). Among the "payments" to upstream farmers being considered by the project are training in the best agricultural practices for saving water by more sophisticated downstream commercial farmers, transfers of old piping from mines that upstream farmers can use to line earthen irrigation canals, and wages to laborers who remove invasive plants. The degree to which these payments are conditional is unclear (other than, of course, the wage for plant removal). The Maloti-Drakensberg Transfrontier project (Diederichs and Mander, 2004), which spans parts of Lesotho and South Africa, is a larger project that includes a PWS component. The project falls in the catchment that supplies approximately $25 \%$ of South Africa's water. The main identified threats are invasive plants in and along the rivers and land degradation from burning and grazing.

Within the Sabie-Sand catchment, research is underway to examine how payments for catchment protection can be incorporated into the management plan of a newly created Catchment Management Association (CMA). South Africa's National Water Act (Act No.36 of 1998) called for the creation of CMAs as a way to decentralize catchment management. The Sabie River catchment was chosen as one of the first locations for creating a CMA. Researchers are exploring the potential for payments from commercial game farmers, urban water users, and a local bird club that wants to pay communities to protect riparian habitat and stream flow needed by birds.

\subsection{Proposed Project: East Arc Mountains, Tanzania ${ }^{12}$}

The Uluguru Mountain watershed is home to forty-eight villages and an estimated population of 90,000 people. Forests in the watershed are believed to be important for downstream hydrologic services that benefit Dar es Salaam, the coast, and the Morogoro region. Deforestation is threatening these forests. A scoping project, run by WWF, CARE, and IIED and entitled "Equitable Payments for Watershed Services" is exploring the potential for PWS in the watershed (as well as payments for other services like carbon sequestration). ${ }^{13}$

This scoping project is documenting the hydrologic relationships and the potential buyers and sellers of watershed services. Preliminary evidence suggests that the watershed's forests can no longer hold enough water during the wet season, which leads to water shortages downstream. The goal of the project is to "help mountain communities stabilize and improve the productivity of their farms as well as prevent further forest loss.” Downstream water authorities and private sector corporations are the intended buyers of the hydrologic services, but the scientific case is being developed before the buyers will be approached for participation. Similar scoping work is also being conducted in another nearby watershed (South Nguru).

Tanzania is also home to another proposed project that has a PWS component: the IUCN-WANI Pangani River Basin Demonstration Site Project. Although the project is not primarily a PES project, it proposes to initiate feasibility studies with a particular eye toward establishing the willingness on the part of users to pay for water services.

\subsection{Proposed Project: Sasumua Water Treatment Plant, Kenya ${ }^{14}$}

\footnotetext{
${ }^{12}$ Sources: WWF (2006) and WWF (n.d.).

${ }^{13}$ ICRAF has recently become involved in the same initiative through its PRESA project (Pro-poor Rewards for Environmental Services in Africa; Swallow and Yatich, 2007).

${ }^{14}$ Sources: World Agroforestry Centre (2006).
} 
The Sasumua Water Treatment Plant treats water for the Nairobi Water Company, which provides water services to the Kenyan capital. The plant draws water from a few small watersheds in the Aberdares Mountains. The treatment plant is affected by two water quality problems: sedimentation, which clogs the intakes, and water contamination from nutrients and agrichemicals. The plant expends funds each year to clear its intakes of silt ( $\$ 50,000 /$ year) and treat the water prior to delivering it to consumers ( $\$ 100,000 /$ year). The sedimentation and pollution originate mainly from runoff from upstream land users and from effluent from towns.

The project is exploring the potential for the plant to pay upstream land users to alter their land use in ways that reduce sedimentation and agricultural pollution. The costs of engineering approaches to removing silt and pollution serve as the benchmarks from which a PWS scheme will be evaluated. Project proponents note that making the case for payments is easier when the damage is already visible, as it is at the Sasumua plant. However, the same proponents note that reversing the damage is more costly than preventing it from arising in the first place. The necessary payments are anticipated to be needed on an ongoing basis and would be paid either out of the existing treatment plant budget (from cost savings in avoided dredging and treatment costs) or through additional "conservation fees" to water users. The institutional structure for making the payments must be worked out and could be difficult given overlapping jurisdictions over different components of the water system (Nairobi Water Company, Athi River Water Services Board, ${ }^{15}$ Water Resource Management Authority, and the Nairobi City Council). The project is connected to a larger agricultural development project called the Kenya Agricultural Productivity and Sustainable Land Management (KAPSLM) project.

Kenya is also home to a newly proposed PWS project in watersheds associated with Mt. Kenya and the Tana River. The project, a collaboration of the GreenWater Credits project and the International Fund for Agricultural Development, is part of a larger program entitled "Pro-poor Rewards for Environmental Services in Africa.” One other Kenyan program that sometimes appears in lists of African PWS schemes is the Western Kenya Integrated Ecosystem Management Project. The objective of this project is to reduce soil erosion and associated pollutant transport into Lake Victoria, which is a critical fresh water resource (GEF, 2005). A key project component is to encourage adoption of sustainable land management (SLM) practices that sequester carbon and pay local communities for carbon credits. The SLM initiative is believed to lead to a co-benefit of reduced sediment, nutrient, and chemical runoff into surface waters. This project shows that, in some cases, payments for non-water ecosystem services may generate water-related services.

\section{Why so Few PWS Schemes in Africa?}

Africa is the most capital-poor, inhabited continent on earth and thus, not surprisingly, most of its rural populations depend upon ecosystem services for their livelihoods. With regard to water, more than 300 million of the estimated 800 million who live on the African continent live in water-scarce environments. Sub-Saharan Africa includes eleven of the sixteen nations of the world having less than $1000 \mathrm{~m}^{3} /$ head/year of water, a situation described as `absolute water scarcity' where food shortages are a constant threat and water shortage can only increase (FAO 1995). Forecasts (Johns Hopkins, 1998) estimated that by 2025, about one in two Africans will be living in countries that are confronted with water stress or water scarcity (stress implies less than $1,500 \mathrm{~m}^{3}$ /capita/year). Pollution from agricultural runoff, industrial discharges, and sewage exacerbates water scarcity.

If water is so scarce and increasing its supply so important, why are there so few PWS programs in Africa? Payments for watershed services proponents frequently cite a common list of obstacles to the development of PES schemes: lack of technical and market information, limited institutional experience, inadequate legal framework, limited successful business models, suspicion of markets for public goods

\footnotetext{
${ }^{15}$ http://www.awsboard.com/faqs.asp
} 
and equity concerns. Based on this review of PWS and the African continent, these characteristics are also likely barriers to African PWS development (as in other continents), but there seem to be more fundamental barriers, which are described in this section.

To begin to answer the question of why there are so few PWS initiatives in Africa, it is instructive to rephrase the question: "Why are there a large and growing number of PWS initiatives in Latin America and so few in Africa?” The contrast between the two regions is instructive for understanding constraints to using PWS in Africa and elsewhere.

\subsection{Is there substantially less demand for water services in Africa?}

A recent global review of all types of PES concluded (Waage 2006: 3), "[t]he barriers first and foremost stem from finding willing and able buyers" and "[t]he reasons for this unrealized demand range from a lack of awareness through a sense that PES is too nascent and thus risky." It has been established that water scarcity and, to a lesser extent, water quality are important issues in Africa. Thus perhaps it is true that the economics favor PWS, but lack of information and familiarity with the PWS mechanism constrains demand.

However, even if the values for watershed services were clearer and the hydrologic relationships between land uses and hydrologic services were more transparent, securing financing for payments requires two things: (1) institutions capable of excluding nonpayers (free-riders); and (2) water service consumers with the ability to pay. Below, the potential institutional sources of payments for watershed services in Latin America and Africa, and the ability of Latin Americans and Africans to pay, are considered.

\subsubsection{Institutional Sources of Payments}

In general, payments for watershed services come from five sources: hydroelectric power suppliers, large industrial users, municipal water suppliers, irrigation water users and general tax revenues. Below, these potential sources in Latin America and Africa are contrasted. It is worth mentioning that in most PWS cases in the world, existing revenue streams are being used to make the conservation payments. Only in a few cases have rates paid by end-users been raised. Thus the financial health of institutions is an important prerequisite for PWS schemes, a quality for which African institutions are not well known.

\section{Hydroelectric Power}

Africa generates little electricity in comparison to other regions of the world (almost half is generated by South Africa alone) and less than $20 \%$ of the generation comes from hydroelectric sources (Lokolo, 2004; United Nations, 2004). In contrast, almost 70\% of Latin America's substantially greater electricity production comes from hydroelectric sources (United Nations, 2004). Unlike Latin America and parts of Asia, Africa does not have high hydroelectric potential because so much of the continent is subject to a semi-arid climate with periodic droughts. Sub-Saharan Africa has hydroelectric potential of 710 Terawatt hours (TWh), of which 6\% was developed in 1990s. Latin America, in contrast, had 3280 TWh of potential, of which $12 \%$ was developed (i.e., almost ten times the amount is currently produced). The hydroelectric capability of Africa is mainly located in its most institutionally weak nations: Democratic Republic of Congo, Cameroon, Ethiopia and Madagascar (Lokolo, 2004). Moreover, in terms of potential numbers of payers, Latin America and the Caribbean nations have the highest electricity coverage (84\%) of any region in the developing world, whereas Africa has the lowest (around $10 \%)$.

\section{Municipal Water Suppliers}

As with hydroelectric power, Africa also has fewer formal water delivery systems and fewer citizens connected to them in comparison to Latin America (UN-HABITAT, n.d.). Thus there are fewer people that can easily be charged for domestic water. A study of water supply and independent providers in ten African capital cities (including Nairobi) estimates that in the majority of these cities, only one- 
quarter to one-half of the households have access to piped supplies, with the rest of the households relying on independent providers or traditional sources (Collignon and Vézina 2000). In Kenya, there are 201 urban centers in the country, but only 109 have piped water systems and all are government-run (World Bank, 2004a). Within Nairobi, only 42\% of households have water connections serviced by the Nairobi Water and Sewerage Company (Athi River Water Services Board). ${ }^{16}$ Almost all other households obtain water from kiosks, vendors and illegal connections. Of the existing customers, more than $40 \%$ do not receive 24 -hour service, $30 \%$ receive water about once every two days, and $10 \%$ receive water only once a week. Asking such customers to pay an additional charge for hydrologic services might be difficult even if they were not as poor.

Rural households have much lower connection rates (Donkor, 2006). For example, in the Sudan in 1995, urban housing units with piped water constituted 62\%, whereas in the rural areas, the coverage was only 18\%. In Malawi in 1990, the figure for urban areas was $75 \%$ and for rural areas $16 \%$. Most Latin American nations have higher rates of urban access to piped water and, more importantly, much higher rates of urbanization. About three-quarters of the Latin American population is urban (similar to the United States). In contrast, only 35\% of the African population lives in urban areas, although this figure is projected to double by 2030 (UNDP, 2002).

Furthermore, investing in watershed management is not an obvious priority for African municipal water supply systems. Urban water systems are caught in a cycle of declining investment, quality of service, and financial returns, characterized by (a) low coverage and unreliable service, (b) high levels of unaccounted-for water and unpaid bills, (c) poor financial management, (d) revenues insufficient to cover operations and maintenance costs, and (e) inadequate commercial management (World Bank, 2001; 2004b). For example, studies in Dar es Salaam (Cudjoe and Okonski) and Nairobi (Gulyani et al., 2005:4) found that about half of the water that entered the system was "unaccounted-for" through leaks, theft, and unbilled or uncollected revenues. In Mombasa, Kenya, all of the 57,500 connections are metered, but about one-third of these meters do not work (unaccounted-for water was estimated at $40 \%$ ). Billing and collection efficiencies for Nairobi and Mombassa, Kenya were between 60 and 70\%, with accounts receivable representing more than two years service in Nairobi (Gulyani et al., 2005).

Scurrah-Ehrhart (2006) recounts an interview with a water authority in Tanzania on the topic of PWS. Although results from studies conducted in the water authority's catchments implied water users were willing to pay for water services, the water authority disputed such results. It claimed that it was difficult simply to collect the current low user fees from their customers. A potentially higher fee associated with a PWS scheme would be even more difficult.

\section{Irrigation Associations}

Payments for watershed services schemes involving the irrigated agricultural sector are not common on any continent. In Africa, agriculture represents the bulk of water withdrawal. The FAO (2005) reports that for the African continent as a whole, $86 \%$ of water withdrawals are directed towards agriculture and this percentage is even higher in the arid and semi-arid regions. In Latin America, however, water use by agricultural sector is also high at 73\% (AQUASTAT, 2007).

Latin America has seen a much greater degree of irrigation network privatization and decentralization to irrigation user associations than Africa (AQUASTAT, 2007; FAO 2005). Although the difference between the two regions will likely decline over time (e.g., all new irrigation schemes in Kenya between 1992 and 2003 were private), the absence of irrigation-driven PWS schemes in Latin America where conditions are more conducive suggest that African irrigation-driven PWS schemes are unlikely in the near term.

\section{Industrial Water Users}

Industrial water users are self-supplied industries not connected to a distribution network. No specific data on differences between Latin American and African industrial users were identified.

\footnotetext{
${ }^{16}$ Summary available at http://www.awsboard.com/faqs.asp
} 
Industrialization is certainly much lower in Africa than in Latin America, and thus were this sector to be a potentially important source of funds for PWS schemes, one would expect to see more industry-driven PWS programs in Latin America. These were not found. However, in Africa, the frequency of mining activities in water scarce environments may counterbalance Latin America's advantage in this regard.

\section{General Tax Revenues}

The final institutional source of PWS financing is general tax revenues. With regard to this potential source of funds, Africa has much less capacity for PWS financing than Latin America. Africa has smaller government budgets (just over half), larger populations (almost double), higher levels of poverty (more than three times higher), and higher rates of government expenditures expressed as a percentage of GDP (despite the African GDP being much lower). All of these observations imply that Africa has much less capacity than Latin America for drawing on tax revenues to fund PWS programs. ${ }^{17}$

\subsubsection{Ability to Pay}

Getting African water users to pay for hydrologic services is made difficult by high levels of poverty. Thirty-four of the forty-nine least developed countries are African (FAO, 2005). In 1993, the World Bank-estimated poverty rates for Africa and Latin America were $50 \%$ and $15 \%$, respectively (World Bank, 2000). However, poverty also makes the required payments for PWS lower in Africa than in Latin America (i.e., African suppliers' opportunity costs are lower). Thus there is no clear relationship between poverty and the ability of beneficiaries to pay for water services.

However, the high-profile development goal to increase Africans' access to safe drinking water makes it politically more difficult to insist that water users pay a higher fee. The weighted average of population with access to safe drinking water for fifty-two African countries covering the period from 1992 to 1994 was 46\%, while in Latin America the rate was 80\% (Gleick, 1998). Even in South Africa, where the percentage of the population with access to safe water is relatively high by African standards, restricting water access to non-payers is controversial. Opponents to pricing water often point to a serious outbreak of cholera in 2000 that occurred when water prices increased in Kwazulu Natal and many poor residents sought other, less safe sources of water as substitutes. Because water is a larger portion of their budget, poor residents likely have a much higher price elasticity of demand for water than non-poor residents. ${ }^{18}$

On top of these constraints, one must also recognize that Africans already use much less water per capita than in other areas of the world and they pay more per unit. For example, in Kenya, Gulyani et al. (2005) found that mean per capita daily water use is thirty-three liters for the poor and forty-four liters for the nonpoor, and both groups pay an average of about US $\$ 3.50 / \mathrm{m}^{3}$ (almost six times what a consumer pays in Atlanta, Georgia, USA).

\subsection{Transaction Costs}

When discussing barriers to PES development in Africa, many authors identify high transaction costs as important barriers (Muramira, 2005; Grieg-Gran et al., 2006; Ochieng et al., 2007). Although transaction costs are frequently identified as a problem in all nations (Bellagio Group, 2007), there are reasons to believe that PWS schemes in Africa may be particularly affected by such costs.

\subsubsection{Land Distribution}

Although average population densities per square kilometer in the late 1990s are similar in Latin America and Africa (about 25 people/ $\mathrm{km}^{2}$; McDevitt, 1999), 73\% of Latin Americans (including

\footnotetext{
${ }^{17}$ Sources: Government consumption and expenditures (UN 2004b, Fan and Rao 2003); Population (www.overpopulation.org/); and Poverty Rates (World Bank 2000).

${ }^{18}$ If there are wealthier, large consumers of water in a market, a tiered pricing system, which charges low rates for use below some threshold level and rapidly increasing rates above the threshold, may be one way to raise revenues without placing a heavy burden on the poor.
} 
Caribbean) lived in urban areas in 1995, compared to only 35\% of Africans (UN-HABITAT, n.d.). Land ownership is much more concentrated in Latin America than in Africa (Lastarria-Cornhiel et al., 1999). Thus in Latin America, PWS schemes are more likely to contract with a smaller number of large landowners, whereas in Africa, they must contract with many small land users/owners. Note that the less concentrated distribution of land in Africa also implies that should a PWS be feasible, it is more likely to be pro-poor than in Latin America.

\subsubsection{Transboundary Watersheds}

Africa has sixty transboundary river basins which together cover more than $60 \%$ of the continent's total area. Thus water management in Africa is often transboundary in nature, but the same is true in South America (Wolf et al. 1999). Thus it is not clear that transboundary water management is more problematic in Africa. However, in Africa, regardless of whether watersheds cross national boundaries, watersheds are more likely to have greater cultural heterogeneity among upstream and downstream users than in Latin America. For example, upstream and downstream users in Africa are more likely to speak different languages. Such heterogeneity may increase the costs of creating mutual understanding, trust, and other forms of social capital, which lower the transaction costs of contracting.

\subsubsection{Making and Enforcing Contracts}

A PWS scheme is a contracting scheme and thus the factors that are typically identified as curtailing business activity apply to PWS development: e.g., regulatory environment, rates of literacy, judicial system, availability of information, trust, and corruption. Although most nations in Latin America are not paragons of business-friendly societies, they do tend to have higher indicator scores than Africa. For example, of the sixty-four most corrupt nations in the world (Transparency International, 2006), twenty-five are from Sub-Saharan Africa (out of forty-eight African nations). Only eight are from Latin America (out of twenty-one nations).

A more directly relevant indicator of transaction costs is the measure of the cost of enforcing contracts in a nation. The World Bank measures this cost as court fees and attorney fees expressed as a percentage of the debt value. In Latin America and the Caribbean, the value is 23\%, while in SubSaharan Africa, the value is almost double at $42 \% .{ }^{19}$

Furthermore, in Africa, many of the water suppliers, hydroelectric power sources and other potential water buyers are controlled by the state. Thus, governance is an important issue. ScurrahEhrhart (2006) relates the story of the Tanzania Electricity Supply Company Ltd. (TANESCO). TANESCO currently pays the Ministry of Water and Livestock Development an annual 'user fee," of which a proportion is given to Water Basin Authorities to carry out catchment management activities. In practice, however, the Water Basin Authorities do not carry out these activities.

\subsection{Land Tenure Security}

When discussing barriers to PES development in Africa, other authors have identified the African land tenure situation as important (e.g., Muramira, 2005; Mwangi and Mutunga, 2005; Ochieng et al., 2007). ${ }^{20}$ Although tenure systems are diverse on every continent, a review of global tenure trends (Lastarria-Cornhiel et al., 1999) argues that Latin American tenure systems have historically been based on private ownership, whereas in Africa most land is held under customary tenure that provides access to land to all recognized members of the community. Thus, PWS schemes in Africa will frequently have to address multiple sources of formal and informal authority over a given tract of land. Indeed, in South Africa, the program in the Ga-Selati River catchment had made a lot of progress in the design phase, but stalled because of conflicting land claims and ongoing reform over water allocations (N. King, per. comm. 2007).

\footnotetext{
${ }^{19} \mathrm{http}: / /$ www.doingbusiness.org/ExploreTopics/EnforcingContracts/

20 One could argue that issues related to land tenure belong under "transaction costs," but because many authors in the PES literature seem to treat tenure issues as different from transaction costs, they are separated here.
} 
Customary tenure systems in Africa generally do not permit land sales, particularly to persons outside the community, and even leasing can be complicated by tenure insecurity (i.e., someone leasing land could gain rights over it), which makes rental rates higher than they normally would be (LastarriaCornhiel et al., 1999). Compared to Latin America watersheds, African watersheds are much more likely to have many people with usufruct land rights. Thus PWS contracts, which typically contract for actions that curtail access and use to land, may be more difficult in Africa than in Latin America.

Given the likelihood of multiple property claims on a piece of land, payments in Africa are more likely to be at the community level than the household level, which complicates project design. Although there are examples of community-based revenue sharing schemes (e.g., CAMPFIRE in Zimbabwe) and community-based PES (e.g., Nhambita Community Carbon Project in Mozambique), not all African nations recognize customary tenure or "communities" (villages, village councils, etc.) as autonomous legal personalities, particularly when the land in question is "wild" forests or wetlands. Even when such tenure systems and local institutions are recognized, designing a community-based contract that induces the required individual behaviors is much more difficult than in situations with single owners with secure property rights.

\subsection{Enabling Legislation \& Policies}

Reports on PES related to Africa (Waage et al., 2005; Muramira, 2005; Mwangi and Mutunga, 2005; Scurrah-Ehrhart, 2006) argue that a key constraint is the lack of "enabling legal, regulatory and administration elements.” Nations in which there is some PES activity (Uganda, Kenya and S. Africa) have some enabling legislation (Ruhweza and Muhumure, 2005). However, no inventories have been completed in nations without PES, and thus one cannot clearly observe a causal relationship between the enabling legislation and PES development.

Other nations, such as Costa Rica, have demonstrated that the policy environment can catalyze PES initiatives. Other nations, such as the United States (cities of New York City, Boston, and Syracuse with respect to their watershed management activities) have also demonstrated that the regulatory environment can directly stimulate PWS contracting. Local government authorities may be reticent to engage in PWS schemes, but through suasion and regulatory threats, that reticence can be reduced. Moreover, it has been amply demonstrated that enabling legislation is important for carbon markets.

In some cases, there may be legislation that explicitly forbids a PWS-related activity. For example, South Africa's National Water Act prohibits some activities for which someone might want to make a payment, such as removal of vegetation from a riparian zone or stopping agriculture in a riparian zone (King et al., 2005). In other cases, authority over water and land use may be too decentralized to allow for effective coordination across a catchment (e.g., if water user's associations are defined at the sub-catchment level).

However, no clear case for the lack of enabling legislation being an important barrier to PWS development has been made. In many African nations, there is legislation for channeling "user fees" (called "abstraction fees") to watershed management. ${ }^{21}$ There may be weaknesses in the systems (Scurrah-Ehrhart, 2006) and an unwillingness to charge such fees, but the authority to do so exists in many African nations. Indeed, the summary of the East African and South African PES inventories (Katoomba Group, 2006) identifies the lack of supporting legislation as a barrier, but notes that "in most countries, policies establishing the right to buy and sell ecosystem stewardship services have not been essential for pilot activity in PES.”

\subsection{Supporting Institutions}

A report summarizing PES inventories for East Africa and South Africa (Katoomba Group, 2006) claims that, "Most countries cited lack of necessary institutions — such as certification bodies; financial intermediaries; national registries for ecosystem services; and so on - across the value chain from seller

\footnotetext{
${ }^{21}$ See, for example, the country water law documents at http://www.silsoe.cranfield.ac.uk/iwe/ expertise/waterlaw.htm
} 
to buyer that increase current PES transaction costs." However, it is not obvious that certification bodies, financial intermediaries and national registries for ecosystem services have been important in the development of PWS in Latin America. A much more likely institutional barrier to PWS development in Africa, in comparison to Latin America, is simply the unsophisticated state of most water management agencies in Africa and the absence of the will and means to charge water users for water quantity and quality improvements.

\subsection{Hydrology}

It is difficult to determine if there is a fundamental difference in the hydrologic regimes of Africa and Latin America that makes PWS schemes less likely in Africa. Average annual precipitation in Africa is estimated at about of $678 \mathrm{~mm}$ with wide variability (FAO, 2005), whereas average precipitation in South America and Central America is much higher with most of Central and South America receiving between 1,000 and 3,000 mm/year. ${ }^{22}$ With less precipitation and surface and subsurface flows, interventions over similar land areas may have smaller impacts on downstream flows in Africa and PWS schemes may have to operate a larger scale to achieve comparable impacts. At large scales, however, measuring impacts from PWS programs may be difficult because of the larger set of confounders and the potentially longer time-lags in hydrologic response associated with low precipitation.

\subsection{Awareness and Human Capacity}

When discussing critical barriers to PES development in Africa, some authors identify a simple lack of awareness about the idea and the lack of capacity to design and implement a PES scheme (Muramira, 2005; Mwangi and Mutunga, 2005; Katoomba Group, 2006; Ochieng et al., 2006). ${ }^{23}$ The concept of PWS schemes is relatively new and given the constraints on information transmission in Africa, one would expect PWS development in Africa to be moving more slowly than in Latin America.

In 2005, practitioners established an East and Southern African working group on PES to share information and conduct training for practitioners and policymakers. Development donors are also conducting PES training for Africans. Thus in the next five years, one should be able to test the hypothesis that lack of human capacity is a major bottleneck. If this lack of awareness and capacity is truly a constraint on PWS development, one should see a lot more PWS development.

However, if an absence of hydrologic knowledge is a key constraint, then one might not see more PWS development in the next five years. Participants at a 2005 African PES workshop concluded that the "[t]echnical capacity to identify and monitor links between resource management and provision of ecosystem services is weak in all countries." ${ }^{24}$ A search of water-related articles from Water Resources Abstract for a dozen African and a dozen Latin American nations showed Latin American nations had about double the number of articles per nation. Even removing a few outliers (Mexico, Brazil, South Africa) left Latin American nations with almost 60\% more articles. If articles are a good proxy for the state of knowledge, then Latin America has a much better level of understanding of the hydrologic relationships relevant to PWS schemes.

\subsection{Insights from South Africa}

Given the barriers to the development of PWS listed above, it should come as no surprise that the majority of African PWS activity is taking place in South Africa. Relative to the rest of Sub-Saharan Africa, South Africa has a better business climate, higher income levels, greater scientific capacity, better understanding of the nation's hydrology, greater institutional capacity, a stronger national water law that

\footnotetext{
${ }^{22}$ http://www.r-hydronet.sr.unh.edu/

${ }^{23}$ See also summary of Workshop "Building Foundations for Pro-Poor Ecosystem Services in Africa." Eighth Public Meeting of the Katoomba Group 19-22 September, 2005, Uganda.

http://www.katoombagroup.org/africa/uganda.htm

24 "Building Foundations for Pro-Poor Ecosystem Services in Africa." Eighth Public Meeting of the Katoomba Group 19-22 September, 2005, Uganda. http://www.katoombagroup.org/africa/uganda.htm
} 
makes provision for the use of economic instruments in water management (Act No 36 of 1998), and higher rates of access to safe water.

In its two operational PWS programs (section 3.1 and 3.2), South Africa has managed to address the imperative of assisting the poor and circumvent the problems that arise from complex tenure systems. They have done so by adopting a public works program approach that permits targeting of benefits to the disadvantaged and avoids contracting with land users (i.e., focuses on government lands). This approach also leads to broad national support for the programs. Moreover, the contracts in these programs are for activities for which compliance is relatively easy to monitor (removing invasive plant species on a plot of land, or rehabilitating a wetland).

Although general tax revenues fund the two current PWS schemes in South Africa, the infrastructure that has been developed lends itself to municipal and private sector involvement. From this perspective, the South African program has much in common with the Costa Rican Programa de Pagos de Servicios Ambientales, which is also a national-level program into which non-national government agents can pay to secure ecosystem services for their private benefit. Given that South Africa has better governance than much of Africa, it is unclear whether such an infrastructure could be built elsewhere in the near future. Trust that a government agency would deliver services commensurate with the level of payment requested is generally low in Africa.

\section{Discussion and Conclusion}

As noted in the Introduction, the paucity of on-the-ground PWS initiatives precludes a definitive discussion of an "African PWS model" or "regional PWS trends in Africa." Nevertheless, there are some common elements of existing and proposed African PWS initiatives.

First, and most importantly, poverty alleviation and equitable wealth distribution are key objectives in most African PWS projects (the exception is the Kenyan Sasumua initiative). Poverty issues are important components of Latin American PWS schemes, but the top priority of Latin American PWS schemes is the watershed services. In Africa, poverty alleviation and services are viewed as equally valued joint products of PWS schemes, or the provision of watershed services is merely viewed as a cobenefit of the poverty alleviation scheme (e.g., Working for Water Program). The implied social targeting that comes with a focus on poverty alleviation will likely increase the transaction costs and decrease the level of watershed services provided by PWS in Africa. Whether PWS can have a large impact on poverty remains to be seen. PWS proponents tend to not view PWS as an important poverty alleviation tool unless the program is a large-scale public works initiative like South Africa's Working for Water program (e.g., Bond, 2006b; Bellagio Group, 2007). The appeal of a PWS scheme that provides employment benefits may explain the African interest in the potential role of PES to restore degraded ecosystems (Ruhweza \& Muhumure, 2005).

Second, as in most other nations, there are no programs that involve trading under a regulatory cap on the level of ecosystem services, nor trading schemes that are induced because of increasingly more stringent regulatory requirements. Third, the two existing programs in South Africa depend on general tax revenues for financing. The choice of such financing stems from a strong program emphasis on economic empowerment and poverty alleviation rather than ecosystem services, and from the political controversy surrounding raising water prices in a poor nation. The planned programs in Africa are hopeful for financing that comes from water users directly, but none have clearly secured such a funding source. South Africa's WfW program shows that the dichotomy that some PWS proponents make between "public payment schemes" and "self-organized private deals" is not a strict one: the government can maintain an institutional infrastructure through which individual beneficiaries of ecosystem services (e.g., private companies) can make their payments to service suppliers. Such a system currently operates in Costa Rica, where private beneficiaries can set up self-organized deals (e.g., Heredia water utility) or pay into the centralized national payment system (e.g., Energía Global hydroelectric company). 
When PWS programs are government-funded, like the programs in South Africa, some observers claim they are less "sustainable" than self-organized deals between the beneficiaries and the sellers of the service. Such claims, however, implicitly assume that market transactions are somehow more sustainable than government programs funded by taxation and user fees. There is no evidence to support such a claim. If anything, large government programs that lead to large numbers of rent-seekers seeking to protect and expand the program may be more sustainable than market transactions.

For example, the Working for Water program in South Africa, with former president Nelson Mandela as its "patron in chief," is so popular that it is slated to continue until at least 2020 (WWF, 2006). According to a former South African Minister of Water (K. Asmal), the Ministry of Finance now sees the program as a positive contribution to economic, not just environmental, goals and thus also supports it (East and Southern Africa Katoomba Group, 2006). Rather than sustainability being a weakness of government-financed PWS, a more important problem is the difficulty that governmentfunded programs have in adapting to changing conditions and new information that call for a redistribution of their investments.

Another argument frequently made in the PES gray literature and presentations is that taxfinanced PWS programs are inherently less cost-effective than private payment programs. However, given that most water and hydroelectricity suppliers in Africa are government-run or regulated private entities, there is no reason to believe they will be any more cost-effective. Even when the buyer is a private enterprise, the fact that many private enterprises engage in these deals for reasons of corporate social responsibility and reputation also suggests that they may be no more cost-effective than taxfinanced initiatives. Indeed, the greater scrutiny of government programs may lead tax-financed PWS to be more cost-effective over time.

PWS schemes that connect water users directly to water suppliers, however, do have the advantage of generating new money for conservation. However, this additional money may not necessarily go to the area to which the water users are directing their payments. Other governmental or nongovernmental agencies may simply redirect their funds to other areas: in other words, the new money will be a substitute, rather than a complement locally (globally, it may indeed be a complement). Such substitution has been observed in Costa Rica (e.g., Heredia water supply company’s PWS program, which receives no payments from the government’s PES program (L. Gámez, per. comm., 2007).

In conclusion, for all of the reasons discussed in section 4, there will likely be fewer PWS schemes in Africa than elsewhere. However, these barriers to PWS development do not imply there are no opportunities for PWS. There are already a couple of large-scale initiatives and a number of incipient initiatives that may succeed in establishing PWS schemes. Further experimentation and informationsharing over the next five years should offer a clearer picture of the potential for PWS to achieve environmental and social objectives on the African continent.

\section{References}

AQUASTAT. 2007. AQUASTAT: FAO's global information system on water and agriculture. http://www.fao.org/ag/agl/aglw/aquastat/

Bellagio Group. 2007. Payments for Watershed Services. Building on pilot experiences to mainstream a tool for sustainable conservation and development. International Meeting at the Rockefeller Foundation's Bellagio Conference Centre, Como, Italy. March 12 - 17. Organized by Fundación Natura Bolivia, IIED, Centre for International Forestry Research and EcoFund Ecuador.

Bond, I. 2006a. A review of payments for watershed services. Presentation to NORAD. October http://www.iied.org/NR/forestry/documents/IvanBondpresentationtoNORAD.pdf 
Bond, I. 2006b. Payments for Watershed Services. Presentation at the Workshop "Building Foundations for Pro-Poor Ecosystem Service Payments in Africa,” September 20-22, Queen Elizabeth National Park, Uganda http://www.katoombagroup.org/docs/pdf/katoomba8/Bond__Payments_for_Watershed_Services2.ppt

Collignon, B., and M. Vézina. 2000. Independent Water and Sanitation Providers in African Cities: Full Report of a Ten-Country Study. World Bank, Water and Sanitation Program,

Washington, D.C.

Cudjoe, F. and K. Okonski. 2006. The reality of water provision in urban Africa. In The Water Revolution: Practical Solutions to Water Scarcity, ed. K. Okonski. Sustainable Development Network, pp.175-200.

Diederichs, N. and M. Mander. 2004. Payment for Environmental Services Baseline Study Final Report. Maloti-Drakensberg Transfrontier Project. December. FutureWorks! Everton, South Africa.

Donkor, S.M. 2006. Water in Africa: Management Options to Enhance Survival and Growth. Our Common Earth. United Nations Economic Commission for Africa. Addis Ababa, Ethiopia.

East and Southern Africa Katoomba Group. 2006. Catalyzing Payments for Ecosystem Services in East \& Southern Africa. Proceedings of the East and Southern Africa Katoomba Group Meeting; Cape Town South Africa. November 8-10. Kirstenbosch Botanical Gardens Cape Town, South Africa. http://www.katoombagroup.org/docs/pdf/katoombaXI/ESA_proceedings.pdf

Fan, S. and N. Rao. 2003. Public Spending in Developing Countries: trends, determination and impact. EPTD Discussion Paper no. 99, IFPRI, Washington, DC.

Ferraro, P.J. 2001. Global Habitat Protection: Limitations of development interventions and a role for conservation performance payments. Conservation Biology 15(4): 990-1000.

Food and Agriculture Organization (FAO). 1995. Water sector policy review and strategy formulation: A general framework. Food and Agriculture Organization, United Nations Rome, Italy.

Food and Agriculture Organization (FAO). 2005. Irrigation in Africa in Figures: AQUASTAT Survey -2005, Water Report 29, FAO, Rome, Italy.

Ferraro, P.J. Forthcoming. Asymmetric Information and Contract Design for Payments for Environmental Services. Ecological Economics.

Gleick, P.H. 1998. The World's Water 1998-1999: The Biennial Report On Freshwater Resources. Island Press, Washington, DC.

Gulyani, S., D. Talukdar, and R.M. Kariuki. 2005. Water for the Urban Poor: Water Markets, Household Demand, and Service Preferences in Kenya. Water Supply and Sanitation Sector

Board Discussion Paper Series, No.5 (January). Washington, DC: World Bank.

Grieg-Gran, M., S. Noel and I. Porras. 2006. Lessons learned from payments for environmental services. Green Water Credits Report 2, ISRIC Report 2006/5, ISRIC, Wageningen, Netherlands.

http://www.isric.org/Webdocs/Docs/GWC2_Lessons\%20learned\%20(July\%202006).pdf

Jindal, R. 2006. Carbon Sequestration Projects in Africa: potential benefits and challenges to scaling up. EarthTrends Environmental Essay Competition Winner. World Resources Institute. 
http://earthtrends.wri.org/features/view feature.php?fid=68\&theme=3 (extended version: Jindal, R., B.

Swallow, and J. Kerr. 2006. Status of carbon sequestration projects in Africa:

Potential benefits and challenges to scaling up. World Agroforestry Centre, Working Paper).

Johns Hopkins (1998). Solutions for a Water-Short World. Population Report, Vol. XXVI, No. 1, September 1998. Johns Hopkins Population Information Program, Baltimore, Maryland, United States

Katoomba Group 2006. Summary of Country-level PES Inventories Carried out in East and South Africa. East and Southern Africa Katoomba Group, Kampala, Uganda.

http://www.katoombagroup.org/africa/documents/inventories

King, N., M. Damon and G. Forsyth. 2005. An Inventory of Current Ecosystem Service Payments, Markets, and Capacity Building in South Africa. 8 September. Forest Trends, Washington, DC.

http://www.katoombagroup.org/africa/documents/inventories

Lastarria-Cornhiel, S. and J. Melmed-Sanjak, with B.R. Phillips. 1999. Land Tenancy in Asia, Africa, and Latin America: a look at the past and a view to the future. Land Tenure Center, University of Wisconsin, Madison, WI.

Lecocq, F. and K. Capoor. 2005. State and Trends of the Carbon Market. 9 May. International Emissions Trading Association. Geneva, Switzerland.

Lokolo, M.C. 2004. Enlightening a Continent in the Dark- Prospects for Hydropower Development in Africa. United Nations Symposium on Hydropower and Sustainable Development, Beijing, 27-29 October.

http://www.un.org/esa/sustdev/sdissues/energy/op/hydro_lokolo_ppt.pdf

McDevitt, T.M. 1999. World Population Profile: 1998. U.S. Bureau of the Census, Report WP/98, U.S. Government Printing Office, Washington, DC.

Muramira, T.E. 2005. Overview of payment for ecosystem services in Uganda. Presented at the Workshop "Building Foundations for Pro-Poor Ecosystem Service Payments in Africa,"

September 19-22, Queen Elizabeth National Park, Uganda.

http://www.katoombagroup.org/docs/pdf/katoomba8/planning/Muramira\%20-

\%20Overview\%20of\%20PES\%20in\%20Uganda.ppt

Mwangi. S. and C. Mutunga. 2005. Overview of PES in Kenya. Presented at the Workshop "Building Foundations for Pro-Poor Ecosystem Service Payments in Africa,” September 19-22, Queen Elizabeth National Park, Uganda.

http://www.katoombagroup.org/docs/pdf/katoomba8/Mwangi and Mutunga_Overview_of_PES_in_Kenya. $\mathrm{ppt}$

Mutunga, C. and S. Mwangi, 2006. Inventory for Ecosystem Service Payment in Kenya. March. Forest Trends, Washington, DC.

http://www.katoombagroup.org/africa/documents/inventories

Ochieng B, Otiende B and Rumley R. 2007. African Regional Workshop on Compensation for Ecosystem Services (CES), May 22 - 24, 2006, Nairobi, Kenya. ICRAF Working Paper no. 35. Nairobi, Kenya: World Agroforestry Centre.

www.worldagroforestrycentre.org/downloads/publications/PDFs/WP14959.PDF 
Ruhweza, A. and M. Masiga. 2005. An Inventory of Initiatives/Activities and Legislation Pertaining to Ecosystem Service Payment Schemes (PES) in Uganda. September. Forest Trends, Washington, DC. http://www.katoombagroup.org/africa/documents/inventories

Ruhweza, A. and S. Muhumure. 2005. Strategic PES in Africa. Presentation to the Private Katoomba Meeting associated with the Workshop "Building Foundations for Pro-Poor Ecosystem Service Payments in Africa,” September 19-22, Jinja, Uganda.

http://www.katoombagroup.org/docs/pdf/katoomba8/Ruhweza_and_Korutaro_Strategic_Planning_for_PES in_Africa.ppt

Scurrah-Ehrhart, C. 2006 Tanzania Inventory of Payments for Ecosystem Services. 16 July. Forest Trends, Washington, DC.

http://www.katoombagroup.org/africa/documents/inventories

Swallow, B. and T. Yatich, 2007. RUPES -Africa: Propoor Rewards for Environmental Services

In Africa (PRESA) The Global Event on Payments/Rewards for Environmental Services. Lombok, Indonesia. http://www.worldagroforestry.org/sea/Networks/RUPES/download/ISCLombokJan07/Annex\%208\%20B $\underline{\text { S.pdf }}$

Transparency International. 2006. Corruption Perceptions Index (CPI). Transparency International, Berlin, Germany.

Turpie, J.K. 2004. Maloti Drakensberg Transfrontier Conservation and Development Programme: Ecosystem Services Trading Project. Report on Ecosystem Service Trading in the Region. September. FutureWorks! Everton, South Africa.

Turpie, J.K. and J. Blignaut. 2005. Payments for Ecosystem Services: towards improved biodiversity conservation and water security in South Africa, a semi-arid, developing country. Presentation at the Workshop on Payments for Environmental Services (PES) - Methods and design in developing and developed countries, .June, Titisee, Germany

http://www.cifor.cgiar.org/pes/publications/pdf_files/PES_SA_Presentation.pdf

UN-HABITAT (United Nations Human Settlements Programme). n.d. Human Settlements Conditions and Trends. Statistics Programme. Global Urban Observatory and Statistics Unit. http://ww2.unhabitat.org/habrdd/stat1prog.htm

UNDP (United Nations Development Programme). 2002. Human Development Report 2002. New York Oxford, Oxford University Press.

United Nations. 2004a. Energy Studies Yearbook: 2004. New York: United Nations.

United Nations (Economic and Social Council). 2004b. Committee of Experts on Public Administration, Third session, New York, 29 March-2 April 2004, Item 3 of the provisional agenda, Revitalizing public administration, Basic data on government expenditure and taxation, Report of the Secretariat. 17 February 2004

Waage, S., S. Scherr, M. Jenkins and M. Inbar. 2006. A Scoping Assessment of Current Work on Payments for Ecosystem Services in Asia, Latin America, and East \& Southern Africa. Adapted from the full report submitted to the UNDP-GEF project: “Institutionalizing Payments for Ecosystem Services," Supplement III. Building National Capacity for PES.

wcln.org/modules.php?name=UpDownload\&req=getit\&lid=7 
World Agroforestry Center. 2006. Laying the foundations for a payment for watershed services scheme for the Sasumua Reservoir, Central Highlands of Kenya Kenya Agricultural Productivity and Sustainable Land Management Project, PES Component. Proposal, 23 June.

World Bank. 2000. World Development Report 1999/2000. The International Bank for Reconstruction and Development/The World Bank. Oxford University Press, Oxford, Great Britain.

World Bank. 2001. “Kenya: Review of the Water Supply and Sanitation Sector.” Report 22182. World Bank, Washington, DC.

World Bank. 2004a. Kenya: Country Assistance Strategy. Report 28825-KE. World Bank, Washington, DC.

World Bank. 2004b. "Kenya: Nairobi Water and Sewerage Institutional Restructuring Project: Project Appraisal Document.” Report 28825-KE. World Bank, Washington, DC.

Wolf, A.T., J.A. Natharius, J.J. Danielson, B.S. Ward, J.K. Pender. 1999. International River Basins of the World. International Journal of Water Resources Development 15(4): 387-427.

Wunder, S. 2007. The Efficiency of Payments for Environmental Services in Tropical Conservation Conservation Biology 21 (1), 48-58.

WWF (World Wildlife Fund). n.d. Valuing the Arc: linking science with stakeholders to sustain natural capital. Washington, DC.

WWF (World Wildlife Fund). 2006. Payments for Environmental Services: an equitable approach for reducing poverty and conserving nature. June. IWashington, D.C. 
Table 1. PES projects in Africa

\begin{tabular}{|c|c|c|c|c|}
\hline Country & Initiative & Organization & Status & Source \\
\hline Cameroon & $\begin{array}{c}\text { Cameroon timber } \\
\text { concessions }\end{array}$ & $\begin{array}{l}\text { Conservation } \\
\text { International } \\
\end{array}$ & Proposed & $\begin{array}{l}\text { http://epp.gsu.edu/pferraro/special/C } \\
\text { oncessionConceptDescription.pdf }\end{array}$ \\
\hline Guyana & $\begin{array}{c}\text { Guyana timber } \\
\text { sales agreement }\end{array}$ & $\begin{array}{l}\text { Conservation } \\
\text { International }\end{array}$ & Ongoing & $\begin{array}{l}\text { http://epp.gsu.edu/pferraro/special/C } \\
\text { oncessionConceptDescription.pdf }\end{array}$ \\
\hline \multicolumn{5}{|l|}{ Kenya } \\
\hline $\begin{array}{l}\text { Arabuko- } \\
\text { Sokoke Forest }\end{array}$ & $\begin{array}{l}\text { Arabuko-Sokoke } \\
\text { Forest } \\
\text { Management and } \\
\text { Conservation } \\
\text { Project }\end{array}$ & $\begin{array}{l}\text { BirdLife International, } \\
\text { Nature Kenya }\end{array}$ & Ongoing & $\begin{array}{c}\text { http://www.birdlife.org/action/groun } \\
\text { d/arabuko/index.html }\end{array}$ \\
\hline Amboseli & $\begin{array}{c}\text { Wildlife } \\
\text { conservation in } \\
\text { Amboseli, Kenya }\end{array}$ & FAO & Ongoing & $\begin{array}{l}\text { ftp://ftp.fao.org/es/esa/roa/pdf/roane } \\
\text { ws07.pdf }\end{array}$ \\
\hline $\begin{array}{l}\text { Kitengela } \\
\text { region }\end{array}$ & $\begin{array}{l}\text { Kitengela wildlife } \\
\text { conservation lease } \\
\text { program }\end{array}$ & $\begin{array}{l}\text { The Wildlife } \\
\text { Foundation }\end{array}$ & Ongoing & $\begin{array}{l}\text { http://www.usaid.gov/ke/ke.naremg } \\
\text { nt/success_kitengela.htm }\end{array}$ \\
\hline $\begin{array}{l}\text { Machakos } \\
\text { and Kitui, } \\
\text { Kwale and } \\
\text { Busia }\end{array}$ & $\begin{array}{l}\text { Kenya forestry } \\
\text { initiatives }\end{array}$ & $\begin{array}{c}\text { Bureau of } \\
\text { Environmental Analysis } \\
\text { International }\end{array}$ & Ongoing & $\begin{array}{c}\text { http://www.beainternational.org/Cas } \\
\text { eReports.htm }\end{array}$ \\
\hline Mount Kenya & $\begin{array}{l}\text { Il Ngwesi group } \\
\text { ranch and } \\
\text { partnership }\end{array}$ & $\begin{array}{l}\text { Lewa Wildlife } \\
\text { Conservance }\end{array}$ & Ongoing & http://www.lewa.org/ilngwesi.php \\
\hline $\begin{array}{l}\text { Nyando, } \\
\text { Yala, and } \\
\text { Nzoia river } \\
\text { basins }\end{array}$ & $\begin{array}{l}\text { Western Kenya } \\
\text { integrated } \\
\text { ecosystem } \\
\text { management } \\
\text { project }\end{array}$ & $\begin{array}{c}\text { ICRAF- Kenya } \\
\text { Agriculture Research } \\
\text { Institute }\end{array}$ & Ongoing & $\begin{array}{l}\text { http://www.isric.org/Webdocs/Docs } \\
\text { /GWC2_Lessons\%20learned\%20(Ju } \\
\text { ly\%202006).pdf }\end{array}$ \\
\hline \multirow{2}{*}{$\begin{array}{l}\text { Southern } \\
\text { Kenya }\end{array}$} & $\begin{array}{c}\text { Shompole } \\
\text { ecotourism } \\
\text { development } \\
\text { project } \\
\end{array}$ & $\begin{array}{l}\text { Shompole Community } \\
\text { Trust }\end{array}$ & Ongoing & http://www.shompole.com/ \\
\hline & $\begin{array}{c}\text { Kenya agricultural } \\
\text { productivity and } \\
\text { sustainable land } \\
\text { management }\end{array}$ & GEF \& the World Bank & Ongoing & $\begin{array}{c}\text { http://www.gefonline.org/projectDet } \\
\text { ails.cfm?projID=2355 }\end{array}$ \\
\hline $\begin{array}{l}\text { Kingangop } \\
\text { plateau }\end{array}$ & $\begin{array}{c}\text { Kinangop } \\
\text { grasslands } \\
\text { important } \\
\text { biodiversity area } \\
\end{array}$ & Nature Kenya & Unknown & $\begin{array}{c}\text { http://www.iucn.nl/english/funds/pu } \\
\text { rchase/engels/projecten_eng.htm\#ke } \\
\text { n04 }\end{array}$ \\
\hline \multicolumn{5}{|l|}{ Madagascar } \\
\hline & $\begin{array}{l}\text { JIRAMA water } \\
\text { debits for water } \\
\text { protection }\end{array}$ & $\begin{array}{l}\text { JIRAMA (Madagascar's } \\
\text { Energy Company) }\end{array}$ & Incipient & $\begin{array}{l}\text { http://www.katoombagroup.org/afri } \\
\text { ca/documents/inventories/madagasc } \\
\text { ar\%20inventory.doc }\end{array}$ \\
\hline $\begin{array}{l}\text { Andasibe- } \\
\text { Mantadia }\end{array}$ & $\begin{array}{c}\text { Andasibe- } \\
\text { Mantadia } \\
\text { Biodiversity } \\
\text { Corridor } \\
\end{array}$ & ANGAP & Ongoing & $\begin{array}{l}\text { http://carbonfinance.org/Router.cfm } \\
\text { ?Page=Projport\&ProjID=9638 }\end{array}$ \\
\hline Maroantsetra & $\begin{array}{c}\text { Makira } \\
\text { conservation site }\end{array}$ & $\begin{array}{l}\text { Wildife Conservation } \\
\text { Society (WCS) }\end{array}$ & Ongoing & $\begin{array}{l}\text { http://www.wcs.org/international/A } \\
\text { frica/madagascar/makira }\end{array}$ \\
\hline
\end{tabular}




\begin{tabular}{|c|c|c|c|c|}
\hline Masoala & $\begin{array}{l}\text { Masoala National } \\
\text { Park }\end{array}$ & WCS & Ongoing & $\begin{array}{c}\text { http://www.wcs.org/sw- } \\
\text { around_the_globe/Africa/174291 }\end{array}$ \\
\hline \multicolumn{5}{|l|}{ Namibia } \\
\hline & $\begin{array}{c}\text { Namibia } \\
\text { Community } \\
\text { Based Natural } \\
\text { Resources } \\
\text { Management } \\
\end{array}$ & WWF & Ongoing & $\begin{array}{c}\text { http://www.povertyfrontiers.org/ev } \\
\text { en.php?ID=1112_201\&ID2=DO_T } \\
\text { OPIC }\end{array}$ \\
\hline \multicolumn{5}{|l|}{ Sierra Leone } \\
\hline Gola Forest & $\begin{array}{l}\text { Sierra Leone } \\
\quad \text { forest } \\
\text { conservation } \\
\text { concession }\end{array}$ & $\begin{array}{l}\text { Conservation Society of } \\
\text { Sierra Leone }\end{array}$ & Ongoing & $\begin{array}{l}\text { http://www.cbd.int/doc/external/cop } \\
\text {-08/ma-gola-2006-03-27.pdf }\end{array}$ \\
\hline \multicolumn{5}{|l|}{ South Africa } \\
\hline $\begin{array}{l}\text { Olifants and } \\
\text { Sabi Rivers }\end{array}$ & $\begin{array}{l}\text { Developing } \\
\text { markets for } \\
\text { watershed } \\
\text { protection } \\
\text { services and } \\
\text { improved } \\
\text { livelihoods } \\
\end{array}$ & IIED & Completed & $\begin{array}{c}\text { http://www.iied.org/NR/forestry/pro } \\
\text { jects/water.html }\end{array}$ \\
\hline $\begin{array}{l}\text { Sabie-Sand } \\
\text { catchment, } \\
\text { Mpumalanga, } \\
\text { and the Ge- } \\
\text { Selati River, } \\
\text { Limpopo } \\
\text { Province }\end{array}$ & $\begin{array}{c}\text { Feasibility } \\
\text { assessment for } \\
\text { implementing } \\
\text { payment schemes }\end{array}$ & IIED and CSIR & Incipient & $\begin{array}{c}\text { http://www.isric.org/Webdocs/Docs } \\
\text { /GWC2_Lessons\%20learned\%20(J } \\
\text { uly\%202006).pdf }\end{array}$ \\
\hline $\begin{array}{l}\text { Makuleke } \\
\text { region }\end{array}$ & $\begin{array}{l}\text { Makuleke tourism } \\
\text { initiative }\end{array}$ & $\begin{array}{c}\text { South African National } \\
\text { Parks } \\
\end{array}$ & Ongoing & $\begin{array}{c}\text { http://www.propoortourism.org.uk/s } \\
\text { africa_cs2.pdf }\end{array}$ \\
\hline \multirow[t]{3}{*}{$\begin{array}{l}\text { Richtersveld } \\
\text { National Park }\end{array}$} & $\begin{array}{l}\text { Richtersveld } \\
\text { National Park }\end{array}$ & $\begin{array}{l}\text { South African National } \\
\text { Parks }\end{array}$ & Ongoing & $\begin{array}{c}\text { http://epp.gsu.edu/pferraro/special/ } \\
\text { RICHTERSVELDSouthAfricalease } \\
\text {.pdf }\end{array}$ \\
\hline & $\begin{array}{l}\text { Working for water } \\
\text { program }\end{array}$ & $\begin{array}{l}\text { South African } \\
\text { Department of Water } \\
\text { Affairs and Forestry }\end{array}$ & Ongoing & http://www.dwaf.gov.za/wfw/ \\
\hline & $\begin{array}{l}\text { Working for } \\
\text { Wetlands } \\
\text { Programme } \\
\end{array}$ & $\begin{array}{l}\text { South African } \\
\text { Department of Water } \\
\text { Affairs and Forestry }\end{array}$ & Ongoing & $\begin{array}{c}\text { http://www.sanbi.org/research/wetla } \\
\text { ndprog.htm\#prog }\end{array}$ \\
\hline $\begin{array}{l}\text { Cape Floristic } \\
\text { Region }\end{array}$ & $\begin{array}{c}\text { South Africa - } \\
\text { CAPE } \\
\text { biodiversity } \\
\text { conservation and } \\
\text { sustainable } \\
\text { development } \\
\text { project } \\
\end{array}$ & $\begin{array}{l}\text { National Botanical } \\
\text { Institute of S.A. }\end{array}$ & Unknown & $\begin{array}{c}\text { http://go.worldbank.org/ET73YFR4 } \\
\text { I0 }\end{array}$ \\
\hline \multicolumn{5}{|l|}{ Tanzania } \\
\hline $\begin{array}{c}\text { East } \\
\text { Usambara } \\
\text { Mountains } \\
\text { and Uluguru } \\
\text { Mountains } \\
\text { Catchment }\end{array}$ & $\begin{array}{c}\text { Equitable } \\
\text { payments for } \\
\text { watershed } \\
\text { services: } \\
\text { Delivering } \\
\text { poverty reduction } \\
\text { and conservation }\end{array}$ & WWF & Ongoing & $\frac{\underline{\text { http://assets.panda.org/downloads/f }}}{\text { actsheet_pes_english.pdf }}$ \\
\hline
\end{tabular}




\begin{tabular}{|c|c|c|c|c|}
\hline $\begin{array}{l}\text { Pangani River } \\
\text { Basin }\end{array}$ & $\begin{array}{l}\text { Pangani River } \\
\text { Basin } \\
\text { Management } \\
\text { Project } \\
\end{array}$ & IUCN & Ongoing & $\begin{array}{l}\text { http://www.panganibasin.com/proje } \\
\text { ct/index.html }\end{array}$ \\
\hline & $\begin{array}{l}\text { Participatory } \\
\text { Forest } \\
\text { Management in } \\
\text { Tanzania } \\
\end{array}$ & Tanzanian Government & Ongoing & http://nfp.co.tz/forest-cons.html \\
\hline $\begin{array}{l}\text { Pangani River } \\
\text { Basin }\end{array}$ & $\begin{array}{l}\text { Pangani River } \\
\text { Basin } \\
\text { Management } \\
\text { Project }\end{array}$ & IUCN & Proposal & $\begin{array}{l}\text { http://www.panganibasin.com/proje } \\
\text { ct/index.html }\end{array}$ \\
\hline Mvomero & $\begin{array}{c}\text { The Participatory } \\
\text { Environmental } \\
\text { Management } \\
\text { Programme } \\
\end{array}$ & CARE, et al. & Proposed & $\begin{array}{c}\text { http://www.katoombagroup.org/afri } \\
\text { ca/documents/inventories/TanzaniaI } \\
\text { nventory_7-06.pdf }\end{array}$ \\
\hline \multicolumn{5}{|l|}{ Uganda } \\
\hline $\begin{array}{l}\text { Lake George } \\
\text { and Lake } \\
\text { Kyoga }\end{array}$ & $\begin{array}{l}\text { Integrated Lake } \\
\text { Management } \\
\text { Project }\end{array}$ & $\begin{array}{l}\text { DFID, the ILM, MRAG } \\
\text { Ltd and CARE }\end{array}$ & Completed & $\begin{array}{l}\text { http://p15166578.pureserver.info/il } \\
\text { m/docs/general/End\%20of\%20Proj } \\
\text { ect\%20Summary\%20Report.pdf }\end{array}$ \\
\hline $\begin{array}{l}\text { Lake Victoria } \\
\text { Region }\end{array}$ & $\begin{array}{l}\text { Uganda Breweries } \\
\text { Ltd. National } \\
\text { Wetlands } \\
\text { Program - } \\
\text { wetlands } \\
\text { management and } \\
\text { education } \\
\text { activities }\end{array}$ & $\begin{array}{l}\text { Uganda Breweries Ltd. } \\
\text { (funding) }\end{array}$ & Completed & $\begin{array}{c}\text { http://www.isric.org/Webdocs/Docs } \\
\text { /GWC2_Lessons\%20learned\%20(J } \\
\text { uly\%202006).pdf }\end{array}$ \\
\hline $\begin{array}{l}\text { Budongo } \\
\text { Forest } \\
\text { Reserve } \\
\end{array}$ & $\begin{array}{l}\text { The Budongo } \\
\text { Forest Reserve }\end{array}$ & $\begin{array}{l}\text { UK Dept. for } \\
\text { International } \\
\text { Development }\end{array}$ & Ongoing & $\begin{array}{c}\text { http://www.odi.org.uk/fpeg/publicat } \\
\text { ions/rdfn/22/e-i.html }\end{array}$ \\
\hline $\begin{array}{l}\text { Bufumira } \\
\text { Islands }\end{array}$ & $\begin{array}{c}\text { Bufumira Islands } \\
\text { Alternative } \\
\text { Energy } \\
\text { Demonstration } \\
\text { Project } \\
\end{array}$ & $\begin{array}{l}\text { Bufumira Islands } \\
\text { Development } \\
\text { Association (BIDA) }\end{array}$ & Ongoing & $\begin{array}{c}\text { http://sgp.undp.org/index.cfm?mod } \\
\text { ule=Projects\&page=ShowProject\& } \\
\text { ProjectID=3891 }\end{array}$ \\
\hline $\begin{array}{l}\text { Bushenyi } \\
\text { District, } \\
\text { Western } \\
\text { Uganda }\end{array}$ & $\begin{array}{l}\text { ECOTRUST } \\
\text { "Trees for global } \\
\text { benefits program" } \\
\text { in Uganda } \\
\end{array}$ & ECOTRUST & Ongoing & $\begin{array}{l}\text { ftp://ftp.fao.org/agl/agll/kageradocs/ } \\
\text { 08case_studies/ug_paper_trees_car } \\
\text { bon_sequestration_summary.doc }\end{array}$ \\
\hline $\begin{array}{l}\text { Kibale and } \\
\text { Mount Elgon } \\
\text { National } \\
\text { Parks }\end{array}$ & $\begin{array}{c}\text { Kibale and Mt. } \\
\text { Elgon National } \\
\text { parks } \\
\text { collaborative } \\
\text { management } \\
\text { scheme } \\
\end{array}$ & $\begin{array}{l}\text { Uganda Wildlife } \\
\text { Authority (UWA) }\end{array}$ & Ongoing & $\begin{array}{l}\text { http://www.iucn.org/places/earo/pu } \\
\text { bs/forest/elgonreview.pdf }\end{array}$ \\
\hline $\begin{array}{l}\text { Mabira Forest } \\
\text { Reserve }\end{array}$ & $\begin{array}{l}\text { The Mabira Forest } \\
\text { Reserve Eco- } \\
\text { tourism Project }\end{array}$ & $\begin{array}{l}\text { National Forest } \\
\text { Authority and GEF }\end{array}$ & Ongoing & $\begin{array}{l}\text { http://sgp.undp.org/web/projects/90 } \\
\text { 98/mabira_green_ventures.html }\end{array}$ \\
\hline $\begin{array}{l}\text { Mgahinga and } \\
\text { Bwindi } \\
\text { Impenetrable } \\
\text { Forest }\end{array}$ & $\begin{array}{c}\text { Bwindi } \\
\text { Impenetrable } \\
\text { National Park and } \\
\text { Mgahinga Gorilla } \\
\text { National Park } \\
\text { Conservation } \\
\end{array}$ & $\begin{array}{l}\text { Uganda's Ministry of } \\
\text { Tourism, Wildlife, and } \\
\text { Antiquities }\end{array}$ & Ongoing & http://www.uwa.or.ug/bwindi.html \\
\hline
\end{tabular}




\begin{tabular}{|c|c|c|c|c|}
\hline $\begin{array}{l}\text { Mount Elgon } \\
\text { and Kibale } \\
\text { National } \\
\text { Parks }\end{array}$ & $\begin{array}{l}\text { Elgon/Kibale } \\
\text { National Parks } \\
\text { carbon } \\
\text { sequestration } \\
\text { projects }\end{array}$ & Face Foundation & Ongoing & $\begin{array}{l}\text { http://www.stichtingface.nl/disppag } \\
\text { e.php?op=30401\&rp=L13|L21\&lan } \\
\text { g=uk }\end{array}$ \\
\hline \multirow[t]{2}{*}{$\begin{array}{l}\text { Ngamba } \\
\text { Island }\end{array}$} & $\begin{array}{l}\text { Chimpanzee } \\
\text { Sanctuary and } \\
\text { Wildlife } \\
\text { Conservation } \\
\text { Project }\end{array}$ & $\begin{array}{l}\text { Uganda Wildlife } \\
\text { Authority (UWA) }\end{array}$ & Ongoing & $\begin{array}{c}\text { http://www.ngambaisland.org/index } \\
\text {.php }\end{array}$ \\
\hline & $\begin{array}{c}\text { Integrated Co- } \\
\text { management of } \\
\text { Lakes through } \\
\text { Beach } \\
\text { Management } \\
\text { Units } \\
\end{array}$ & $\begin{array}{l}\text { Uganda Government \& } \\
\text { DFID }\end{array}$ & Ongoing & http://www.ilm.mrag.co.uk/ \\
\hline $\begin{array}{l}\text { West Nile } \\
\text { Region }\end{array}$ & $\begin{array}{l}\text { West Nile } \\
\text { electrification } \\
\text { project }\end{array}$ & $\begin{array}{l}\text { The World Bank } \\
\text { Prototype Carbon Fund }\end{array}$ & Unknown & $\begin{array}{l}\text { http://carbonfinance.org/Router.cfm } \\
\text { ?Page=Projport\&ProjID=9616 }\end{array}$ \\
\hline \multicolumn{5}{|c|}{ Multiple Countries } \\
\hline $\begin{array}{l}\text { Uganda and } \\
\text { Tanzania }\end{array}$ & $\begin{array}{l}\text { Export Promotion } \\
\text { of Organic } \\
\text { Products from } \\
\text { Africa (EPOPA) } \\
\end{array}$ & Sida & Ongoing & $\begin{array}{l}\text { http://www.grolink.se/epopa/Index. } \\
\text { htm }\end{array}$ \\
\hline $\begin{array}{c}\text { South Africa, } \\
\text { Botswana, } \\
\text { Namibia, } \\
\text { Zimbabwe, } \\
\text { Kenya and } \\
\text { Tanzania } \\
\end{array}$ & $\begin{array}{l}\text { Conservation } \\
\text { Corporation } \\
\text { tourism in Africa }\end{array}$ & CCAfrica & Ongoing & $\begin{array}{c}\text { http://www.iied.org/pubs/pdf/full/9 } \\
\text { 066IIED.pdf }\end{array}$ \\
\hline
\end{tabular}

